\title{
KONSEKWENCJE (BRAKU) ZMIAN PRZEPISÓW PRAWA AUTORSKIEGO A STATUS PRAWNY GIER KOMPUTEROWYCH
}

\section{Uwagi ogólne}

Propozycje zmian przepisów ustawy z dnia 4 lutego 1994 r. o prawie autorskim i prawach pokrewnych (dalej: pr. aut.) to stały element dyskusji nad niedostosowaniem prawa z epoki analogowej do wyzwań, jakie stawia XXI wiek. Ostatnia propozycja uzewnętrzniona rządowym projektem z dnia 9 października 2014 r. zmierza niestety jedynie do częściowego uregulowania materii prawa autorskiego i ponownie pomija postulaty globalnej zmiany paradygmatów. Pozostawienie status quo w zakresie kategoryzacji utworów oraz w dalszym ciągu niewyjaśniony status prawny gry komputerowej może powodować skutki, które nie były do tej pory brane pod uwagę, a które mogą być niekorzystne dla wydawców gier komputerowych. Przedstawiane w doktrynie problemy, jakie towarzyszą grom komputerowym pozostały praktycznie bez echa.

Artykuł ma na celu ukazanie skutków, jakie mogą powstać w sytuacji, w której zarówno doktrynę, jak i orzecznictwo sądowe zdominuje stanowisko, że gry komputerowe to przykład utworów audiowizualnych zapisanych techniką cyfrową. Zważywszy na rozwój orzecznictwa sądowego - przyjęcie takiego stanowiska może być tylko kwestią czasu. Autor artykułu nie zgadza się z tym stanowiskiem i uprzedza przed ryzykiem ponoszenia przez środowiska producentów i wydawców gier komputerowych dodatkowych kosztów, które obecnie ponoszą podmioty dokonujące reprodukcji utworu audiowizualnego na egzemplarzu przeznaczonym do własnego użytku osobistego. 


\section{Gry komputerowe jako subkategoria utworów audiowizualnych}

W literaturze tematu przedstawia się stanowisko traktujące gry komputerowe, czyli utwory multimedialne jako subkategorię dzieł audiowizualnych. ${ }^{2}$ Treść art. 1 ust. 2 pkt. 9 pr. aut. - umożliwia taką kwalifikację, z uwagi na wskazanie, iż przedmiotem prawa autorskiego są utwory audiowizualne, w tym filmy. Możliwe jest zatem występowanie jeszcze innych rodzajów dzieł audiowizualnych. Grupa utworów audiowizualnych jest $\mathrm{w}$ doktrynie powiększana o coraz to nowe przykłady, o czym świadczy m.in. propozycja P. Ślęzaka zaliczenia do tej grupy utworów kinematograficznych, dzieł telewizyjnych, wideoklipów i reklam telewizyjnych. ${ }^{3}$

Próby uznania niektórych utworów multimedialnych, m.in. gier komputerowych, za dzieła audiowizualne uzasadnia się istniejącymi pomiędzy nimi podobieństwami. Podobieństwa te dotyczą zarówno sposobu odbioru obu rodzajów dzieł (ekran kina - ekran komputera lub innego urządzenia przystosowanego do odbioru tych utworów), jak i innych, dotyczących procesu przygotowania lub występujących $w$ tych dziełach. Jako przykład utworu audiowizualnego art. 1 ust. 2 pkt. 9 pr. aut. wskazuje utwór filmowy, którego cechy charakterystyczne - podobnie jak innych utworów - nie zostały określone w tekście tej ustawy. Definicja filmu znajduje się natomiast $\mathrm{w}$ akcie normatywnym $\mathrm{z}$ zakresu prawa publicznego, $\mathrm{w}$ ustawie z dnia 30 czerwca 2005 r. o kinematografii. ${ }^{4}$ Artykuł 4 ust. 1 u. kin. uznaje film za utwór o dowolnej długości, w tym utwór dokumentalny lub animowany, złożony z serii następujących po sobie obrazów z dźwiękiem lub bez dźwięku, utrwalonych na jakimkolwiek nośniku umożliwiającym wielokrotne odtwarzanie, wywołujących wrażenie ruchu i składających się na oryginalną całość, wyrażającą akcję (treść) $\mathrm{w}$ indywidualnej formie, a ponadto, $\mathrm{z}$ wyjątkiem utworów dokumentalnych i animowanych, przeznaczony do wyświetlania w kinie, jako pierwszym polu eksploatacji w rozumieniu przepisów pr. aut.

Przedstawiona definicja filmu, pomimo usytuowania w akcie $\mathrm{z}$ dziedziny prawa publicznego i wątpliwości co do tożsamości terminów „film” i „dzieło filmowe”, zawiera jednak elementy, które uznaje się za wspólne cechy grupy dzieł audiowizualnych. Cechy te mogą również istnieć w niektórych rodzajach utworów multimedialnych, w tym właśnie w grach komputerowych. Należy do nich występowanie serii obrazów pozostających w relacji umożliwiającej ich percepcję w określonej kolejności. Obrazy te powinny wywoływać wrażenie ruchu. Nie jest istotne, czy zostały one zarejestrowane na nośniku fizycznym, a także to, że wrażenie ruchu

\footnotetext{
2 P. Ślęzak, Pola eksploatacji utworów audiowizualnych, Bydgoszcz-Katowice 2006, s. 191; A. Wojciechowska, Autorskie prawa osobiste twórców dzieła audiowizualnego, „Zeszyty Naukowe Uniwersytetu Jagiellońskiego, Prace z Wynalazczości i Ochrony Własności Intelektualnej” 1999, z. 72, s. 66-68. P. Ślęzak, Umowa o rozpowszechnianie filmu, Warszawa 1999, s. 35. Dz.U. Nr 132, poz. 111 z późn. zm. (dalej: u. kin.)
} 
możliwe jest dzięki programowi komputerowemu. Wymienione cechy pozwalają zaliczyć do grupy dzieł audiowizualnych, poza filmami, również dzieła telewizyjne i wideogramy.

Zwolennicy stanowiska zaliczającego dzieła o strukturze nielinearnej - m.in. gry komputerowe do dzieł audiowizualnych podkreślają, że brakuje podstaw, aby „zawężać znaczenie pojęcia utworu audiowizualnego wyłącznie do utworów (...) mających linearną strukturę (...)"5 oraz że z treści pr. aut. nie można wywieść wniosku, że utwór audiowizualny musi w trakcie odtwarzania spełniać wrażenie ruchu. ${ }^{6}$ Tradycyjnie ukształtowane w doktrynie prawa autorskiego stanowisko, iż ruchome obrazy w układzie linearnym są elementem charakterystycznym dla dzieł audiowizualnych wynika ze stosowanej w początkach twórczości filmowej (kinematograficznej) fotograficznej metody rejestrującej utwory filmowe.

W doktrynie przedstawiane są stanowiska, że utwory multimedialne, w tym gry komputerowe, stanowią jednak nowe elementy sfery audiowizualnej. ${ }^{7} \mathrm{Za}$ najważniejszy argument przemawiający za możliwością traktowania utworów multimedialnych - części rozbudowanych gier komputerowych jako dzieł audiowizualnych, uważa się podobieństwo w budowie obu rodzajów dzieł. W utworach audiowizualnych oraz w niektórych utworach multimedialnych mamy do czynienia z tak głęboką integracją składników dzieł, iż dzieła te rozważane są jako całość.

Niektórzy przedstawiciele doktryny zaliczają właśnie gry komputerowe do grupy utworów audiowizualnych, kierując się kryterium ruchu, które, rozumiane szeroko, może obejmować także obrazy wtórnie (przez uczestnika gry) wprawione w ruch. ${ }^{8}$ Obecność programu komputerowego w grze komputerowej nie stanowi przy tym żadnej przeszkody dla takiego stanowiska.

Co prawda w dalszym ciągu brak jest polskich orzeczeń, które potwierdzałyby lub negowały traktowanie gry komputerowej jako utworu audiowizualnego, ale stanowisko takie zostało już zaprezentowane w orzeczeniach sądów zagranicznych. Przykładowo wskazać należy na następujące orzeczenia:

(i) W sprawie Menchie v Multi Media Marketing ${ }^{9}$ pozwany na swojej stronie internetowej prezentował treści pornograficzne, do których dostęp był możliwy po wcześniejszym zakończonym sukcesem uczestniczeniu w krótkiej grze komputerowej. Jednak dla części osób określanych jako knowledgeableusers możliwe było pominięcie gry i bezpośrednie dotarcie do prezentowanej na witrynie treści. Obowiązujące od 1984 r. w Wielkiej Brytanii

\footnotetext{
5 M. Ożóg, Podstawowe pojęcia ustawy z 30.06.2005 r. o kinematografii, „Zeszyty Naukowe Uniwersytetu Jagiellońskiego, Prace z Prawa Własności Intelektualnej” 2009, z. 2, s. 125.

$6 \quad$ P. Ślęzak, Umowa o rozpowszechnianie..., op. cit., s. 26.

7 A. Wojciechowska, Autorskie prawa osobiste twórców dzieła audiowizualnego, „Zeszyty Naukowe Uniwersytetu Jagiellońskiego, Prace z Wynalazczości i Ochrony Własności Intelektualnej” 1999, z. 72, s. 67.

$8 \quad$ Ibidem, s. 68.

9 Podano za: I.J. Lloyd, Information technology law, Oxford 2008, s. 257-258.
} 
przepisy Video Recordings $A c t^{10}$ uznawały za przestępstwo rozpowszechnianie wśród osób niepełnoletnich określonych treści pornograficznych (video nasties) bez stosownego zezwolenia. Artykuł 1 Video Recordings Act uznaje za nagrania wideo serię obrazów (ang. visualimages) spełniających łącznie niżej wymienione warunki: 1) obrazy są połączone $\mathrm{z}$ dźwiękiem albo bez dźwięku, 2) obrazy są stworzone w postaci elektronicznej poprzez wykorzystanie informacji zawartych na dysku, kasecie magnetycznej lub jakimkolwiek innym urządzeniu, które może przechowywać elektronicznie dane, 3) mamy do czynienia z ruchomymi obrazami (ang. movingpictures). Sąd I instancji stwierdził, iż w opisywanym przypadku nie występują ruchome obrazy, zaś wyświetlane na stronie internetowej obrazy - z uwagi na krótki czas ich prezentacji - można jedynie traktować jako serię stałych obrazów (ang. series of stillimages), co nie wyczerpuje przesłanek odpowiedzialności pozwanego, gdyż zarzut nie dotyczy nagrań wideo. Doszło zatem do rozdzielenia w utworze multimedialnym części w postaci gry komputerowej od obrazów ukazywanych na stronie internetowej. Sąd II instancji uznał jednak, iż występowanie połączeń - linków pomiędzy tekstem, dźwiękiem i grafiką jest co prawda charakterystyczne dla gier komputerowych, do których co do zasady nie ma zastosowania Video Recordings Act, lecz nie stanowi to przeszkody do uznania dzieł multimedialnych za nagrania wideo. W omawianym orzeczeniu przyjęto, iż krótki czas prezentacji obrazów nie stanowi przeszkody do uznania rozpatrywanego przypadku za movingpictures, chociaż we wcześniej wydanym przez House of Lords w 1988 r. orzeczeniu w sprawie $R$. v. Gold ${ }^{11}$ wskazano, iż moving pictures obejmują sytuacje, w których są one prezentowane przez dłuższy okres niż ulotna chwila (ang. transient period). Określenie to nie jest precyzyjne, stąd może prowadzić do różnic w orzeczeniach dotyczących podobnych stanów faktycznych.

(ii) Stanowisko, zgodnie z którym gry komputerowe w części dotyczącej efektów wizualnych powinny być traktowane jako utwory audiowizualne prezentowane jest - jako jedno z kilku odmiennych stanowisk - w doktrynie niemieckiej. Uzasadnia je właśnie obecność wywołujących wrażenie ruchu obrazów w grach komputerowych. Wrażenie ruchu nie dotyczy starszych gier. W sytuacji, gdy gra komputerowa zawiera obrazy statyczne, może być ona chroniona w ramach specyficznej dla niemieckiego systemu kategorii praw pokrewnych (Laufbilder), które chronią również „nietwórcze” dzieła fotograficzne. ${ }^{12}$

(iii) Stanowisko polegające na zaliczeniu gry komputerowej do kategorii utworów audiowizualnych zostało przedstawione $\mathrm{w}$ dwóch orzeczeniach sądu

http://www.statutelaw.gov.uk/content.aspx?activeTextDocld=1810866 (data dostępu: 15.09 .2015 r.)

I.J. Lloyd, Information technology..., op. cit., s. 258.

U. Loewenheim, (w:) G. Schricker, Urheberrecht. Kommentar, München 2010, s. 1336. 
w Tokio z 1994 r. w sprawach Namco v Gijutsu Hyoronsha oraz Namco v. Suishin Kogou. ${ }^{13} \mathrm{~W}$ pierwszej z wymienionych spraw powód zarzucił przeciwnikowi, iż stworzona przez niego gra wideo o nazwie Chomp zawiera obrazy prawie identyczne $\mathrm{z}$ tymi, które występują w grze powoda $P A C M A N N$. Powód twierdził, iż gra pozwanego, której egzemplarze były sprzedawane, stanowi reprodukcję gry PACMANN, utrwaloną na stałym nośniku. Zarzucił pozwanemu wkroczenie w zakres jego praw osobistych do utworu - gry PACMANN - poprzez naruszenie prawa do integralności utworu i prawa do autorstwa (ang. paternityright) twierdząc, iż gra video stanowi utwór kinematograficzny. Przepisy japońskiego prawa autorskiego uznają za ten rodzaj utworów (ang. cinematograficworks) utwory, które spełniają łącznie trzy cechy: 1) powstały w wyniku tworzenia efektów wizualnych lub audiowizualnych (przesłanka metody wyrażania), 2) są utrwalone na nośnikach materialnych (przesłanka formy istnienia) oraz 3) stanowią wyraz twórczej ekspresji myśli lub emocji analogicznie do twórczości literackiej i artystycznej (przesłanka treści). W omawianej sprawie Tokio District Court uznał, iż gra PACMANN spełniała wszystkie przedstawione wcześniej przesłanki i stanowi utwór kinematograficzny, zaś pozwany naruszył prawa powoda do reprodukcji i dystrybucji takiego utworu poprzez utrwalenie gry Chomp na nośniku dołączonym do sprzedawanej książki.

(iv) W sprawie Namco v. Suishin Kogou sąd w Tokio uznał, iż prezentowanie przez pozwanego gier wideo na przeznaczonych do tego celu urządzeniach oznacza rozpowszechnienie (ang. public showing) utworów kinematograficznych. ${ }^{14}$

(v) Podobne stanowisko zajął sąd amerykański w sprawie M. Kramer Mfg. Co. $v$ Andrews, która dotyczyła karcianych gier komputerowych (poker) typu arcade. Wskazany sąd uznał, iż kształt i cechy charakterystyczne kart (m.in. kolorystyka, połączenie obrazu z dźwiękiem) pozwalają uznać tę grę komputerową za dzieło audiowizualne. ${ }^{15}$

(vi) Inne orzeczenia wydawały sądy australijskie na podstawie The Copyright Act z 1968 r., który z uwagi na datę wejścia w życie nie operował pojęciem utworu multimedialnego i uznawał za utwór kinematograficzny całość składającą się z pojedynczych obrazów, których sekwencja stwarza iluzję ruchu. Najbardziej znaną sprawą, w której sądy obu instancji uznały grę wideo za utwór kinematograficzny (ang. cinematograph film), był spór Galaxy v Sega. ${ }^{16}$ Strona powodowa $\mathrm{w}$ tej sprawie uprawniona była na podstawie sto-

T. Doi, Infringement of a videogame „Pacmann”, „European Intellectual Property Review” 1994, nr 8, s. 202.

„European Intellectual Property Review” 1984, nr 10, s. 226.

M. Kramer Mfg. Co. przeciwko Andrews, 783 F 2d. 421, 436 (th Cir. 1986).

Galaxy Electronics Pty Ltd przeciwko Sega Enterprises Pty Ltd (1997) 3737 I.P.R. 462, Full Federal Court - podano za: L. York, Australia: copyright-video games, „European Law Review” 1997, nr 8, s. 156-157. 
sownej licencji do wydawania dwóch gier wideo, tj. Virtua Cop i Daytona USA Twin. Przeciwnik procesowy sprowadzał do Australii maszyny do gier komputerowych, w których układzie scalonym przechowywane były kopie wymienionych gier. Sąd uwzględnił roszczenia wydawcy gier o zakazanie sprowadzania kopii gier ustalając jednocześnie, iż gry wideo przechowywane w układzie scalonym urządzenia powinny być chronione, jako utwory kinematograficzne. W orzeczeniu końcowym wskazano następujące okoliczności uzasadniające przyjęcie takiego stanowiska: Po pierwsze, ustawowa definicja utworu kinematograficznego powinna podlegać szerokiej, a nie literalnej interpretacji i mieć zastosowanie do nowych technologii. Po drugie, dokonując analizy gry wideo należy koncentrować się bardziej na efekcie końcowym tego produktu - ruchomych obrazach - niż na środkach używanych do tworzenia tych obrazów. Ruchome obrazy są cechą zarówno gier komputerowych, jak i utworów kinematograficznych. W ocenie sądu I instancji okoliczność, iż gra komputerowa nie zawiera sekwencji pojedynczych obrazów stwarzających iluzję ruchu oraz że program komputerowy gry tworzy w sposób niesystematyczny pojedyncze obrazy, nie stanowi przeszkody do uznania gier wideo za utwory kinematograficzne. Przeszkody takiej nie stanowią również ani obrazy, które pojawiają się na maszynie do gier i nie są przechowywane w pamięci komputera tak jak filmy cyfrowe, ani - zdeterminowana przez twórców gry - interaktywność uczestnika gry, kontrolującego sekwencje efektów wizualnych i dźwiękowych. Sąd II instancji podzielił zaprezentowane powyżej stanowisko sądu niższej instancji i wyraźnie zaznaczył różnice istniejące pomiędzy programem komputerowym stanowiącym zbiór instrukcji, układem scalonym (ang. integratedcircuit), który stanowi przedmiot materialny oraz obrazami (ang. visualimages), które są efektem interakcji pomiędzy programem komputerowym a układem scalonym. Obrazy nie są częścią programu komputerowego, a jedynie jego efektem, możliwe jest bowiem skopiowanie obrazów bez kopiowania programu komputowego, np. poprzez skopiowanie bezpośrednio z ekranu.

(vii) $\mathrm{W}$ orzeczeniu belgijskiego sądu apelacyjnego (The Ghent Court of Appeal) z dnia 19 maja 2014 r. stwierdzono, że definicja utworu audiowizualnego jest tak szeroka (prawo belgijskie), że może obejmować różne nowe formy rozwoju technologicznego - w tym gry komputerowe. Sąd podkreślił również, że następstwo ruchomych obrazów to istotny element właśnie utworów audiowizualnych i to efekty audialne oraz wizualne stanowią najważniejszy aspekt gier komputerowych. W konkluzji sąd stwierdził, że gra komputerowa jest utworem audiowizualnym. 
Konsekwencje (braku) zmian przepisów prawa autorskiego a status prawny...

\section{Egzemplarze gier komputerowych przeznaczone do własnego użytku osobistego a tantiemy $z$ art. 70 ust. $2^{1}$ pkt 4 pr. aut.}

W sytuacji, gdy w dalszym ciągu ustawodawca nie wyjaśnił wątpliwości, co do statusu prawnego gry komputerowej, zaś doktryna i/lub orzecznictwo sądowe uzna gry komputerowego za rodzaj utworów audiowizualnych, to liczyć się należy z możliwością wystąpienia przez organizacje zbiorowego zarządzania prawami autorskimi i pokrewnymi z roszczeniami o zapłatę stosownego wynagrodzenia (tzw. tantiem za nośniki) z tytułu reprodukowania utworu audiowizualnego (gry komputerowej) na egzemplarzu przeznaczonym do własnego użytku osobistego.

Określenie „tantiema za nośniki” odnosi się do prawa do wynagrodzenia z tytułu reprodukowania utworu audiowizualnego na egzemplarzu przeznaczonym do własnego użytku osobistego. Inserty to dołączane do dzienników lub czasopism nośniki materialne (zwykle płyty DVD), na których w sposób cyfrowy zapisane zostały utwory audiowizualne. W przypadku uznania gier komputerowych za utwory audiowizualne będziemy mieli do czynienia z nośnikiem zawierającym gry komputerowe. Wprawdzie aktualnie większość gier komputerowych dystrybuowanych jest on-line, to jednak wciąż pozostają $\mathrm{w}$ ofercie czasopisma z załączonymi nośnikami z grami komputerowymi.

Przypisanie gier komputerowych do utworów audiowizualnych otworzy na nowo dyskusję nad charakterem prawa do wynagrodzenia $\mathrm{z}$ tytułu art. 70 ust. $2^{1}$ pkt 4 pr. aut. W doktrynie można zaobserwować pewną ewolucję oceny charakteru tego prawa do wynagrodzenia. Chodzi mianowicie o zagadnienie - jaki charakter ma prawo do wynagrodzenia za tzw. tantiemy ${ }^{17}$ od nośników (egzemplarzy) zawierających utwory audiowizualne - gry komputerowe, czy jest to prawo bezwzględne, względne, a może „półbezwględne”. Tak właśnie określała to prawo prof. Monika Dąbrowska, która w komentarzu do prawa autorskiego wskazywała, że „wzmocnione, wyposażone $\mathrm{w}$ rozszerzoną skuteczność prawo do wynagrodzenia staje się raczej elementem treści podmiotowego prawa autorskiego”. ${ }^{18}$ Pojęcie ,prawo półbezwzględne" wprowadza dodatkowe utrudnienie w rozwiązaniu problemu, gdyż autorskie prawa majątkowe (podobnie jak osobiste) należą do praw bezwzględnych, które kreują obowiązki polegające na biernym zachowaniu się osób nieuprawnionych, a nie na wkraczaniu w sferę zastrzeżoną, jako sfera możności postępowania dla podmiotu prawa bezwzględnego. Prawom względnym odpowiada natomiast obowiązek ciążący na oznaczonych osobach określonego zachowania polegającego na działaniu lub zaniechaniu. ${ }^{19}$ Oznacza to, że podmiot autorskich praw podmiotowych może w ramach posiadanych ustawowo uprawień żądać od podmiotów

Używam określenia „tantiemy” w stosunku do wszystkich wynagrodzeń określonych w art. 70 pr. aut.

J. Barta, R. Markiewicz (red.), Prawo autorskie i prawa pokrewne. Komentarz, wyd. 5, Warszawa 2011, s. 448.

E. Traple, (w:) J. Barta (red.), System prawa prywatnego. Prawo autorskie, Tom 13, Warszawa 2003, s. 134. 
nieuprawnionych m.in. zaprzestania dalszego naruszenia tych praw, usunięcia skutków tego naruszenia. Zakres przedmiotowy tych żądań został dokładnie określony w przepisach art. 79 pr. aut.

$\mathrm{W}$ przypadku wynagrodzenia $\mathrm{z}$ tytułu reprodukowania utworów audiowizualnych - gier komputerowych na egzemplarzach przeznaczonych do własnego użytku osobistego - prawo autorskie nie przewiduje takich uprawnień. Nie gwarantuje zatem uprawnionym realizacji $\mathrm{w}$ stosunku do podmiotów nieuprawnionych zakazowej i nakazowej sfery zachowań. Twórca nie może zatem spowodować zakazania reprodukowania albo sprzedaży egzemplarzy gier komputerowych przeznaczonych do własnego użytku osobistego w sytuacji, gdy podmiot dokonujący reprodukcji posiada ku temu stosowne zezwolenia (licencje). Może jedynie zażądać wynagrodzenia $\mathrm{z}$ tytułu wymienionego $\mathrm{w}$ art. 70 ust. $2^{1}$ pkt 4 pr. aut. od konkretnego podmiotu. Jego uprawnienie w tym zakresie obejmuje zatem nie wszystkich naruszycieli (nie dochodzi do naruszenia jakichkolwiek praw autorskich), ale podmiotów, które nie uiszczają tantiem. Na tym polega $\mathrm{w}$ tej sprawie różnica między prawami bezwzględnymi skutecznymi erga omnes a prawami względnymi skutecznymi jedynie wobec określonych podmiotów. Dlatego też tantiema ustawowa z art. 70 ust. $2^{1}$ pkt 4 pr. aut. stanowi względne prawo (wierzytelność o zapłatę) domagania się wynagrodzenia przez współtwórców utworu audiowizualnego z tytułu faktycznego korzystania $\mathrm{z}$ tych utworów jako całości, w sposób ściśle określony przepisami art. 70 ust. $2^{1}$ pr. aut., bez związku z posiadaniem przez twórcę/współtwórcę jakichkolwiek autorskich praw majątkowych do utworu audiowizualnego - gry komputerowej jako całości lub choćby do utworu wkładowego do tego utworu w zakresie jego eksploatacji.

W doktrynie nie ma zgody co do charakteru omawianego prawa do wynagrodzenia. Przedstawione stanowisko prof. M. Dąbrowskiej jest stanowiskiem pośrednim, które praktycznie nie wyjaśnia charakteru względnego/bezwzględnego prawa do wynagrodzenia za inserty. Taki względny charakter prawa do wynagrodzenia określonego $\mathrm{w}$ art. 70 ust. $2^{1}$ pr. aut. został ostatnio potwierdzony w doktrynie. Chodzi zwłaszcza o stanowisko P. Ślęzaka ${ }^{20}$ oraz stanowisko M. Bukowskiego przedstawione w najnowszym, bo wydanym w roku 2015 komentarzu do prawa autorskiego pod redakcją D. Flisaka. M. Bukowski podobnie jak wymieniona wcześniej autorka potwierdza, że wynagrodzenie za inserty to prawo o rozszerzonej skuteczności i przysługuje tylko w stosunku do podmiotu, który dokonuje eksploatacji utworu audiowizualnego na polach wskazanych $w$ art. 70 ust. $2^{1}$ pr. aut. Brak spełnienia tego roszczenia nie skutkuje jednak naruszeniem autorskich praw majątkowych i nie rodzi odpowiedzialności przewidzianej w art. 79 pr. aut. ${ }^{21} \mathrm{~W}$ mojej ocenie przedstawione stanowiska uzasadniają tezę: że prawo do stosownego wynagrodzenia $\mathrm{z}$ tytułu reprodukowania utworu audiowizualnego - w tym również gry komputerowej

21 D. Flisak (red.), Prawo autorskie i prawa pokrewne. Komentarz LEX, Warszawa 2015, s. 927. 
na egzemplarzu przeznaczanym do własnego użytku osobistego, chociaż określone w przepisach ustawy autorskoprawnej, to jednak nie stanowi elementu praw autorskich rozumianych jako prawa bezwzględne.

Przedstawione powyżej stanowisko prof. Moniki Dąbrowskiej było powszechnie przytaczane w pozwach składanych przez OZZ i jednocześnie sądy I oraz II instancji chętnie odwoływały się do tego stanowiska. Pozwy te dotyczyły tantiem za utwory audiowizualne, ale gdyby gry komputerowe zostały zaliczone do utworów audiowizualnych, to pozwy mogłyby również dotyczyć tej „,nowej kategorii” dzieł audiowizualnych. Przytoczone stanowisko uzasadniało mianowicie zastosowanie domniemania określonego w art. 105 ust. 1 pr. aut. również w odniesieniu do tantiem za inserty. Ani sądy, ani podmioty występujące z pozwami o zapłatę wynagrodzenia albo z pozwami o realizację roszczenia informacyjnego w trybie art. 105 ust 2 pr. aut. nie odnotowały jednak, że w artykule zatytułowanym ,Negotiorum Gestio w zbiorowym zarządzaniu prawami autorskimi lub pokrewnymi” opublikowanym w pracy zbiorowej, która ukazała się pod koniec 2013 r., ${ }^{22}$ autorka wskazała, że prowadzenie cudzych spraw bez zlecenia (negotiorum gestio) dotyczy wyłącznie autorskich praw podmiotowych. Wydaje się, że w ten sposób autorka wyłącza z domniemania z art. 105 ust. 1 pr. aut. autorskie prawa ,półbezwględne. Skoro art. 105 ust. 1 pr. aut. przyjmowany jest w większości pozwów, jako uzasadnienie legitymacji czynnej OZZ do dochodzenia wynagrodzenia z tytułu tantiem za inserty, to zachodzi konieczność udzielenia odpowiedzi na pytanie o charakter prawa do wynagrodzenia $\mathrm{z}$ art. 70 ust. $2^{1} \mathrm{pkt} 4 \mathrm{pr}$. aut. i usytuowania tego prawa w systemie prawa autorskiego.

Sądy podejmowały próby mające na celu wyjaśnienie podnoszonej kwestii w oparciu o dwa kryteria, tj. kryterium usytuowania przepisów o wynagrodzeniu w strukturze pr. aut. oraz kryterium interpretacji ministerialnej. W przypadku próby wyjaśnienie charakteru wynagrodzenia za inserty na podstawie pierwszego kryterium, sądy uzasadniając bezwzględny charakter tego prawa odwoływały się do treści art. 18 ust. 3 pr. aut., który to przepis odnosi się do wynagrodzenia określonego w art. 70 ust. $3 .^{23}$ Sądy dochodziły zatem do wniosku, że skoro wynagrodzenie będące przedmiotem roszczenia zostało uwzględnione w treści art. 18 ust. 3, który to artykuł znajduje się w Rozdziale 3 zatytułowanym „Autorskie prawa majątkowe” - to nie ulega wątpliwości, że mamy do czynienia z prawem bezwzględnym.

Wydaje się, że przyjęte przez sądy uzasadnienie sprzyja potwierdzeniu następującej tezy - to nie usytuowanie przepisu w strukturze ustawy autorskoprawnej, ale istota tego prawa (zakres uprawnień i obowiązków) przesądza o jego charakterze

22 Publikacja (w:) Oblicza prawa cywilnego. Księga dedykowana Profesorowi Janowi Błeszyńskiemu, K. Szczepanowska-Kozłowska (red.), Warszawa 2013, s. 99-120.

23 Art. 18 ust. 3 pr. aut.: Prawo do wynagrodzenia, o którym mowa w art. 19 ust. 1, art. 19 1 , art. 20 ust. 2-4, art. 201, art. 30 ust. 2 oraz art. 70 ust. 3, nie podlega zrzeczeniu się, zbyciu ani egzekucji. Nie dotyczy to wymagalnych wierzytelności. 
jako prawa bezwzględnego. Omawiane wynagrodzenie jest wynagrodzeniem dodatkowym, niezależnym od praw autorskich, przysługujących producentowi (istniejącym obok praw majątkowych producenta), a jego podstawą nie są „zasady ogólne”, lecz konkretny przepis ustawy - art. 70 ust. $2^{1}$ pr. aut. Ten dodatkowy charakter wynagrodzenia za inserty nie budzi żadnych wątpliwości ani w piśmiennictwie, ani w judykaturze. Tak również jego charakter ocenił Trybunał Konstytucyjny w wyroku z dnia 24 maja 2006 r. $^{24}$ Jest to wynagrodzenie dodatkowe, gdyż zostało przyznane niezależnie od wynagrodzenia, które przysługuje twórcy w związku z prawem bezwzględnym wynikającym ze stworzenia utworu (art. 17 pr. aut.), a więc wyłącznym prawem do korzystania z utworu i rozporządzania nim. To „drugie” wynagrodzenie twórca otrzymał za przeniesienie bezwzględnego prawa na nabywcę.

Odwołując się do usytuowania omawianych przepisów w strukturze ustawy autorsko-prawnej sądy dodatkowo podnosiły, że wynagrodzenie z art. 70 ust. $2^{1}$ pkt 4 pr. aut., podobnie jak bezwzględne autorskie prawo majątkowe ma charakter uprzywilejowany, jako niepodlegające zrzeczeniu się, zbyciu ani egzekucji (art. 18 ust. 3 pr. aut.). To jednak w mojej ocenienie nie narzuca wykładni przepisu, określającego rodzaje eksploatacji utworu, za które należy się współtwórcom dodatkowe wynagrodzenie, w kierunku rozszerzenia katalogu tych pól eksploatacji. Uprzywilejowanie dotyczy tylko tego wynagrodzenia, które zostało w sposób wyraźny przyznane i nie stanowi podstawy objęcia nim takich pól eksploatacji, które pozostały poza ramami przepisu". 25

Dodatkowo sądy uzasadniają akceptację roszczeń o zapłatę wynagrodzeń za inserty treścią decyzji albo interpretacji Ministra Kultury i Dziedzictwa Narodowego. MKiDN w części decyzji udzielających zezwolenia na zbiorowe zarządzanie prawami autorskimi wskazuje, że w ramach uprawnień przysługujących OZZ z mocy art. 104 ust. 1 pr. aut. chodzi o wykonywanie uprawnień wynikających $\mathrm{z}$ ustawy - mieści się inkasowanie wynagrodzenia $\mathrm{z}$ art. 70 ust. $2^{1}$ pkt 4 pr. aut. W sytuacjach, w których decyzje nie zawierają żadnego odniesienia do tantiem - MKiDN wydaje postanowienie wyjaśniające wątpliwości co do treści decyzji w sprawie udzielania zezwolenia na zbiorowe zarządzanie prawami autorskim. W takich sytuacjach MKiDN stwierdza, że OZZ jest uprawnione do wykonywania działań niewymienionych w decyzji. Odnosząc się do tej praktyki ministerialnej można rozważyć, czy organ administracji uprawniony jest w ogóle do kreowania nowych praw bezwzględnych i dostosowywania treści ustawy autorskoprawnej do potrzeb OZZ. Uzasadniona jest przedstawiana w doktrynie teza, że zezwolenie MKiDN na prowadzenie zbiorowego zarządu (art. 104 pr. aut.) reguluje wyłącznie jego dopuszczalność od strony administracyjnej. W doktrynie trafnie wskazuje się, że brak jest aktualnie cywilno- 
Konsekwencje (braku) zmian przepisów prawa autorskiego a status prawny...

prawnego źródła „uprawnień” OZZ. ${ }^{26}$ Powszechnie przytaczane w treści pozwów stanowiska sądów apelacyjnych i SN dotyczące uprawnień OZZ pomijają aspekt historyczny tych uprawnień, które początkowo dotyczyły kategorii tzw. małych praw w całkowicie odmiennej sytuacji prawnej. Zezwolenie MKiDN ma jedynie charakter administracyjny i nie kreuje nowych praw podmiotowych, których wykonywanie w imieniu lub na rzecz uprawnionych podmiotów podejmuje OZZ. Dodatkowo należy postawić pytanie, czy określenie ,inkasowanie” odnoszące się do uprawnienia OZZ określonego w art. 70 ust. 3 pr. aut. nie posiada znaczenia jedynie technicznego dotyczącego wyłącznie sposobu pobierania wynagrodzeń.

Można zatem rozważyć zasadność tezy, że skoro prawu do wynagrodzenia z tytułu tantiem określonych $\mathrm{w}$ art. 70 ust. $2^{1}$ pkt. 4 pr. aut. nie towarzyszy obowiązek innych podmiotów niewkraczania w sferę możności działania zarezerwowaną dla podmiotu tego prawa, to mamy do czynienia z prawem względnym nieobjętym domniemaniem z art. 105 pr. aut. A zatem OZZ nie są uprawnione do dochodzenia tych należności. Jest to tylko jedno stanowisko, przeciwne do tego, które obecnie dominuje w orzecznictwie.

Nie można wykluczyć, że to właśnie „dominujące” stanowisko ośmieli OZZ do wystąpienia z roszczeniami zapłaty tantiem z tytułu reprodukowania utworu audiowizualnego - gry komputerowej na egzemplarzu przeznaczonym do własnego użytku osobistego.

\section{Uprawnieni do żądania zapłaty stosownego wynagrodzenia}

Przedstawione powyżej możliwe skutki braku zmian przepisów prawa autorskiego w odniesieniu do gier komputerowych nie wyczerpują jednak puli problemów występowania $\mathrm{z}$ roszczeniami o zapłatę tantiem za inserty zawierające gry komputerowe. $Z$ treści art. 70 ust $2^{1}$ pr. aut. wynika bowiem, że podmiotami uprawnionymi do otrzymania stosownego wynagrodzenia $\mathrm{z}$ tytułu reprodukowania utworu audiowizualnego - gry komputerowej na egzemplarzu przeznaczonym do własnego użytku osobistego są współtwórcy oraz artyści wykonawcy. O ile określenie współtwórców „typowych” dzieł audiowizualnych nie powinno budzić wątpliwości z uwagi na treść art. 69 pr. pras., to jednak wątpliwości te powstają, gdy uznamy, że utwory audiowizualne obejmują także gry komputerowe. W procesie tworzenia gier komputerowych uczestniczą bowiem podmioty, które nie uczestniczą w procesie powstawania utworów audiowizualnych.

W przypadku dzieł audiowizualnych ustawodawca określił w art. 69 pr. aut. katalog osób, które mogą zostać uznane za współtwórców utworu audiowizualnego $-\mathrm{z}$ tym, że nie jest to wyliczenie wyczerpujące. Wymieniony artykuł wskazuje jako 
współautorów w pierwszej kolejności: reżysera, operatora obrazu, twórcę adaptacji utworu literackiego oraz twórcę stworzonych dla utworu audiowizualnego utworów muzycznych lub słowno-muzycznych oraz twórcę scenariusza. W odniesieniu do gier komputerowych grono potencjalnych współtwórców może być jednak szersze, ponieważ w porównaniu z dziełem filmowym dochodzą zwłaszcza takie osoby jak: twórcy bazowego programu komputerowego wykorzystywanego w grze, programiści realizujący poszczególne efekty wizualno-audialne, osoby przygotowujące dokumentację projektową gry, twórcy gameplay'a oraz storyboardu, animatorzy movingpicture, graficy komputerowi. Nie można jednak automatycznie przenosić rozważań dotyczących współtwórców dzieła filmowego na obszar gier komputerowych, z uwagi na odmienność procesu tworzenia filmów i gier komputerowych. Należy zatem wyeliminować z grona potencjalnych twórców gier komputerowych - występujących w dziełach filmowych: operatora kamery, scenografa, montażystę. Wspólna zarówno dla dzieł filmowych, jak i gier komputerowych jest trudność $\mathrm{w}$ ustaleniu, gdzie w procesie tworzenia przebiega granica między wkładem twórczym a działaniami o charakterze technicznym, pomocniczym i organizacyjnym. Trudność ta wynika z różnych możliwości interpretowania pojęcia twórczości - co jest szczególnie widoczne w przypadku wykorzystywania nowych technologii informatycznych i utworów tworzonych przy pomocy komputera.

Zwrócić należy uwagę, że w niektórych grach komputerowych występują również aktorzy, których postacie (sylwetka, twarz, ruchy ciała, mimika twarzy) są wykorzystywane w tworzeniu postaci fikcyjnych - bohaterów. Gra tych aktorów może zostać uznana za artystyczne wykonanie, zaś wykonywanym utworem może być scenariusz gry komputerowej. ${ }^{27}$ Taka sama kwalifikacja może dotyczyć osób udzielających swojego głosu postaciom fikcyjnym bezpośrednio albo w ramach dubbingowania. Dla przygotowania polskojęzycznych edycji gier komputerowych - zwłaszcza gier typu cRPG - wykorzystuje się głosy popularnych aktorów. ${ }^{28}$ Osoby te powinny być traktowane jako aktorzy odgrywający swoje role. Od artysty wykonawcy wymaga się wykonania utworu w sposób osobisty i indywidualny. ${ }^{29}$ W przypadku osób udzielających głosów, twórczy sposób wykonania może polegać na wyrażeniu głosem (odpowiednia modulacja głosu, wybranie odpowiednich tonów itp.) nastroju i temperamentu bohatera fikcyjnego, oddaniu jego „uczuć”, odzwierciedlenia dynamicznej akcji gry. Do artystów wykonawców mogą zostać zaliczeni również wykonawcy utworów muzycznych wykorzystywanych w grach komputerowych - zarówno instrumentaliści, jak i wykonawcy.

Przykłady gier z wykorzystaniem postaci i głosów aktorów: „Wing Commander” - M. Hamill, J. Rhys-Davies, M. McDowell; "X-Files The Game” - D. Duchowny, G. Anderson.

28 Przykłady gier zagranicznych, w których dubbingu wykorzystano głosy polskich aktorów: „Hopkins FBI” - J. Gajos, P. Fronczewski, R. Pazura; „Baldur's Gate” - m.in. J. Kobuszewski, G. Kownacka, J. Opania. wersytetu Jagiellońskiego, Prace z Wynalazczości i Ochrony Własności Intelektualnej” 1984, z. 36, s. 65. 
W doktrynie polskiej reprezentowany jest pogląd, że artyści wykonawcy - aktorzy powinni zostać włączeni w krąg współtwórców dzieła filmowego, gdyż ich rola w dziele audiowizualnym ma szczególny charakter i aktorzy naznaczają dzieło audiowizualne piętnem osobistej twórczość. ${ }^{30}$ Wydaje się, iż prezentowany pogląd nie będzie miał zastosowania do tych gier komputerowych, w których dzięki technikom motioncapture albo performance capture ,występują” aktorzy. Zachowania aktorów są bowiem odpowiednio modyfikowane przy wykorzystywaniu narzędzi informatycznych.

Reasumując tę część rozważań należy podkreślić, że ewentualna próba ustalenia katalogu współtwórców gier komputerowych oraz artystów wykonawców uprawnionych do żądania wynagrodzenia na podstawie art. 70 ust. $2^{1}$ pkt 4 pr. aut. będzie tym bardziej trudna z uwagi na różnorodność gier komputerowych. Nie każda bowiem gra komputerowa jest przygotowywana w stylu filmowym. Gry typu platformówki, gry logiczne czy tekstowe, pozbawione są rozbudowanych scenariuszy, aktorów, akcji i innych elementów typowych dla dzieł audiowizualnych, np. filmów. Różnorodność rodzajów gier komputerowych prowadzi do wniosku, że nie wszystkie gry komputerowe mogą być ,zaliczone” do specjalnej kategorii (subkategorii) w zbiorze utworów audiowizualnych. Problem dalej zostaje nierozwiązany - jak w katalogu utworów wymienionych w art. 1 ust. 2 pr. aut. kwalifikować te pozostałe gry komputerowe?

\section{Wnioski końcowe}

Postulaty uwzględnienia samodzielnego statusu gier komputerowych w prawie autorskim są jak najbardziej aktualne. Obawy zgłaszane przez część doktryny, że istniejący chaos wprowadza poczucie niepewności nie tylko producentów, ale i użytkowników gier komputerowych dodatkowo potwierdza przeprowadzona powyżej analiza skutków (w ograniczonej sferze tantiem za inserty) uznania gier komputerowych za utwory audiowizualne. Czy skutki te znajdą odzwierciedlenie w rzeczywistości, może zależeć wyłącznie od aktywności organizacji zbiorowego zarządzania prawami autorskimi i pokrewnymi. Jak wynika z praktyki, organizacje te są bardzo aktywne na polu ściągania wszelkich należności.

$\mathrm{W}$ artykule skupiono się na jednym zagadnieniu związanym ze stosowaniem art. 70 ust. $2^{1}$ pkt. 4 pr. aut., jednak skala problemów jest o wiele bogatsza. Przykładowo należy wymienić kwestie dozwolonego użytku osobistego oraz traktowania zagranicznych współtwórców gier komputerowych. Ograniczenia co do rozmiaru artykułu uniemożliwiają głębsze rozważanie w tym zakresie.

30 Zob. A. Wojciechowska, Autorskie prawa osobiste twórców dzieła audiowizualnego, „Zeszyty Naukowe Uniwersytetu Jagiellońskiego, Prace z Wynalazczości i Ochrony Własności Intelektualnej” 1999, z. 72, s. 95-96. Wydaje się, iż prezentowany pogląd nie będzie miał zastosowania do tych gier komputerowych, w których dzięki technikom motioncapture albo performance capture „występuja” aktorzy. Zachowania aktorów są bowiem odpowiednio modyfikowane przy wykorzystywaniu narzędzi informatycznych. 


\section{THE CONSEQUENCES OF (LACK OF) CHANGES IN COPYRIGHT LAW AND THE LEGAL STATUS OF COMPUTER GAMES}

Further proposals for amendments to the provisions of the Act on Copyright and Related Rights still do not include the postulates of the doctrine as to specification of the independent legal status of multimedia works - including computer games. The present situation where computer games are classified according to the needs of the entities trading in copyright contradicts the principle of clarity and certainty of law. The article presents the adverse effects (to a limited extent concerning the remuneration for the so called inserts) triggered by sub-categorizing computer games as audiovisual works. It cannot be ruled out that the copyright collective management organizations will begin vindication of dues for compensation for the reproduction of works - computer games on copies designated for own personal use directly from the publishers of computer games. The Author of the article by pointing out the possible consequences of the recognition of computer games as audiovisual works takes a position that in this regard it is also necessary to amend the provisions of copyright law.

Słowa kluczowe: prawo do wynagrodzenia, gry komputerowe, utwory audiowizualne, artystyczne wykonanie, współautorzy gier komputerowych

Keywords: remuneration for inserts, computer games, audiovisual works, artistic performance, co-authors of computer games 